\title{
COORDINATION OF THE WAR ON POVERTY
}

\author{
Michael S. March
}

After one and one-half years of operation, it is becoming increasingly clear that "total war" on poverty is an exceedingly large and complex undertaking. It is well recognized that President Johnson led the country to a remarkable national consensus on the goal of eradicating poverty. Perhaps less well seen is the significance that this national effort has in providing a unified focus for the planning, organization, and administration of social programs. Success in achieving the goal of eradicating poverty may well require a far-reaching change in public administration:

(I) Want, disease, ignorance, squalor, and idleness-to use Lord Beveridge's list of the giants responsible for poverty ${ }^{1}$-require a many-pronged attack. Even if the causes of poverty were fully understood, many of the tools for eradicating them are still in the design or test stage.

(2) The federal machinery for combating poverty requires teamwork among a dozen federal agencies which administer a wide variety of programs. While these many programs contribute much to the antipoverty effort, only a few are specifically and wholly directed to this objective. The funds available to the Office of Economic Opportunity (OEO) constitute only a part, and not the largest, of the federal resources for combating poverty; and, indeed, some of the largest programs are in other agencies.

(3) The pluralistic principle of our social, political, and economic organization complicates planning and action at the local level. The checks and balances of our federal system of government, with its national, state, and local levels of legislatures, legislation, and administrations, make it difficult to mobilize communities to take comprehensive action and to reach the poor in all the corners of the country. "Creative federalism" must overcome this challenge of complexity.

(4) The injections of new organizations, new approaches, and new programs since I964 have challenged some older institutions and existing methods and have produced many conflicts.

Under these circumstances, high premium attaches to inspired insight in the allocation of resources, good organization, and efficient administration. Because scarcity of resources always prevails, effective coordination is the sine qua non of

* Assistant to the Chief of the Education, Manpower and Science Division of the Burcau of the Budget, in the Executive Office of the President.

The author acknowledges his gratitude to numerous staff members in the Office of Economic Opportunity, the Departments of Labor, Health, Education and Welfare, and in the Bureau of the Budget, as well as persons outside the Government, who contributed insights and facts for this article. However, the views expressed are those of the author and do not necessarily represent those of the Bureau of the Budget or any other agency.

${ }^{1}$ See William Beveridge, Soctal Insurance and Alried Services 6 (1942). 
a successful war on poverty. Vice President Humphrey has commented strongly on this point:

... I hope we can be truly non-parochial in our interagency coordination and cooperation. It will require a degree of interagency cooperation, a degree of functional rather than organizational concern, which has seldom, if ever, been achieved in domestic affairs in this country. ${ }^{2}$

Effective coordination is needed horizontally and vertically among federal, state, local, and private agencies. Poor people and poor families frequently have multiple problems. The delivery of variegated services and other assistance for a long enough period and in concentrated enough form to break the intergenerational cycle of poverty is at best a difficult problem. Subsequent sections examine the problem of coordination at both the national and state-local levels from several standpoints.

The "war on poverty" is a landmark in the focusing of public concern on the broad range of social problems and programs which affect people, and in developing new and more effective approaches for concerting resources and action to strike at the root causes of poverty. In considering the role of coordination in this effort, it is useful to bear in mind that the distant goal of eliminating poverty may appear clear, but the routes and the road maps for reaching the promised land are not.

Many of the roadways have never been traversed or even built; the signposts are often blurred or lacking. Numerous promising routes are blocked by institutional obstacles. Neither the longest residents of poverty-land, nor the most respected sages of higher-income-land, can prescribe with certitude the best route. Some claim to know shortcuts-usually labeled "jobs," "negative income tax," "representation of poor," "social security"-while others counsel carefully planned, long term expeditions along multiple routes to develop the capacities of people, and especially of children and youth, through human investment, and to eliminate the culture of poverty. Many who are involved are convinced that shortages of funds will wreck the whole effort. Planning and action are, moreover, often disrupted by strong disagreements.

If this accurately describes the situation in poverty-land and our state of knowledge regarding the exits from it, there is much good reason for adequate provision for search, for trial and error, for toleration of new ideas and multiple solutions. The need for coordination must be balanced against the importance of innovation. Coordination is not an end in itself, but only a means toward solving complex problems involving action by multiple agencies at least cost. One of the most significant elements of the Economic Opportunity Act is its massive commitment to innovation and the opportunity it affords for innovation. Yet the act places much weight on coordination; and coordination cannot be disregarded, because even in a wealthy

\footnotetext{
${ }^{2}$ Remarks of Vice President Hubert H. Humphrey prepared for the Economic Opportunity Council, March I 2, I965.
} 
society, scarcity of resources is an ever-present, dominant constraint. Thus, without constant, effective husbanding of energies and funds, both in their allocation and their administration, it is a virtual certainty that many urgent needs in our society will continue to go unmet.

The specific objective of coordination in the "war on poverty" is to concert resources and action and to increase the speed and efficiency of response by communities, states, and the federal agencies to meeting the needs of the poor. At the local level it seeks to promote the linkage of related programs to secure concerted antipoverty action in providing services and benefits to enable the poor to obtain self-sufficiency. At the federal and state levels it seeks to elicit the cooperative, united action in allocation of resources and administration of programs which will complement local comprehensive planning and action by both public and private agencies. ${ }^{3}$

\section{The Federal Organization for Coordinating the "War on Poverty"}

Many of the organizational problems in the major new effort against poverty were foreseen in late 1963 and early 1964 by the staff of the Council of Economic Advisers, the Bureau of the Budget, and the special task force on poverty which helped advise President Johnson in developing plans for the "war on poverty." A number of approaches to the organization of the federal effort were carefully considered. But from an early date it was clear that coordination would have a central role and that new patterns of action would have to be devised, particularly at the community level, and that this would have a corresponding effect on the mode of federal action.

In his message to the Congress on March 16, I964, President Johnson called for a "national war on poverty." To prevent the war from becoming "a series of uncoordinated and unrelated efforts-that it [not] perish for lack of leadership and direction," the President recommended establishment of a new Office of Economic Opportunity in the Executive Office of the President. The Director of this Office was to be "directly responsible" for the new programs and was to "work with and through existing agencies of the Government."

The Congress followed the President's recommendations. It enacted the Economic Opportunity Act of I964, approved on August 20, I964, creating the OEO and providing broad authority for coordination of antipoverty programs, including authority for the Director "to call upon other Federal agencies to supply such statistical data ... and other materials as he deems necessary to discharge his

\footnotetext{
${ }^{3}$ Coordination in the War on Poverty, II Office of Economic Opportunity, Congressional PresenTATION 93 (1966). The succeeding sections of this article draw extensively on this document, which provides an authoritative description of coordination as envisioned by the OEO.

H.R. Doc. No. 243, 88th Cong., 2d Sess. 4 (I964).

${ }^{5}$ Sec. 6or, 78 Stat. 528, 42 U.S.C. $\$ 294$ I ( 1964$)$.
} 
responsibilities ... and to assist the President in coordinating the antipoverty efforts of all Federal agencies..."6 and for the President to

direct that particular programs and functions, including the expenditure of funds, of the Federal agencies [which are engaged in administering programs related to the purposes of the act, or which otherwise perform functions relating thereto] shall be carried out, to the extent not inconsistent with other applicable law, in conjunction with or in support of programs authorized under this Act.?

The most far-reaching innovation in the act was the provision in title two for "community action programs" to be conducted, administered, or coordinated through "community action agencies." The community action programs were to provide the glue for binding together fragmented programs and the resources for filling gaps in existing efforts. To strengthen the role of this new set of programs and organizations, Congress provided two sorts of preferences.

Section 2II specifies that "In determining whether to extend assistance under this Act, the Director shall, to the extent feasible, give preference to programs and projects which are components of a community action program...." This section applies to the nine other programs authorized by the act.

Section 6r2 provides that:

To the extent feasible and consistent with the provisions of law governing any Federal program and with the purposes of this Act, the head of each Federal agency administering any Federal program is directed to give preference to any application for assistance or benefits which is made pursuant to or in connection with a community action program approved pursuant to Title II of this Act. ${ }^{9}$

This section is designed to assure preference to community action programs from funds for other related programs administered by agencies other than OEO.

II

\section{Overall Coordination of the Antipoverty Effort}

To provide top-level interagency coordinating machinery, Congress also established an Economic Opportunity Council to "consult with and advise the Director in carrying out his functions, including the coordination of antipoverty efforts by all segments of the Federal Government."10 The Director is Chairman of the Council, which includes the Secretaries of Defense, Interior, Agriculture, Commerce, Labor, Housing and Urban Development, and Health, Education and Welfare, the Attorney General, the Administrator of the Small Business Administration, the Chairman of the Council of Economic Advisers, the Director of Selective Service,

\footnotetext{
${ }^{\circ}$ Sec. $6 \mathrm{II}(\mathrm{a})(\mathrm{I}), 78$ Stat. 532, 42 U.S.C. $\$ 296 \mathrm{I}(\mathrm{a})(\mathrm{I})$ (1964).

${ }^{7}$ Sec. 6 II (a) (3), 78 Stat. 532,42 U.S.C. $\$ 296$ I (a) (3) ( 1964$)$.

${ }^{8}$ Sec. 2 II, 78 Stat. 520,42 U.S.C. $\$ 279$ I (I964).

${ }^{\circ}$ Sec. 612,78 Stat. 533, 42 U.S.C. $\$ 2962$ (1964).

${ }^{10}$ Sec. $604(a), 78$ Stat. 53I, 42 U.S.C. $\$ 2944(a)(1964)$.
} 
and, by invitation, the Federal Co-Chairman, Appalachian Regional Commission, and the Director of the Bureau of the Budget.

At its first meeting, President Johnson stated that he looked to the Economic Opportunity Council "as a domestic national security council for the war on poverty."11 He asked Vice President Humphrey to take a leading role in the "war on poverty" and in the work of the Council. The Vice President was also asked by the President to serve as honorary chairman of a twenty-man National Advisory Council provided by section $605^{12}$ to review the operations and activities of the OEO. ${ }^{13}$

The Cabinet-level Economic Opportunity Council and the staff-level Interagency Working Group of the Council provide a valuable forum within the government for top-level consideration of OEO and related antipoverty programs. At its regular meetings the Council has focused on many key interdepartmental questions such as a minimum wage for poverty-related activities and problems of agricultural migrant workers. It has also covered broad questions of interagency coordination, of churchstate relations, and governmental information systems.

\section{A. The President's Paramount Role}

In popular terms, the "war on poverty" is equated with the new programs under the aegis of the Office of Economic Opportunity. Although there are nine or ten OEO programs budgeted for the three fiscal years $1965-1967$, for annual enacted or proposed appropriations of $\$ .8$ billion, $\$ \mathrm{r} .5$ billion, and $\$ \mathrm{r} .75$ billion dollars, respectively, the total federal antipoverty effort is much broader and larger. OEO has identified some 250 other "great society" and related programs administered by at least fifteen other federal agencies-including programs for education, manpower, health, welfare, social security, housing and urban renewal, and economic development-as contributing to the antipoverty effort.

The President is the only official who has authority to direct and coordinate the manifold aspects of this government-wide federal effort. He alone can give meaning to the broad goals, exercise major initiative in presenting a broad legislative program, establish priorities for allocation of fiscal resources through proposed expenditure and revenue measures, shape the organizational alignment of the numerous cooperating and often competing agencies, and establish the broad administrative policies which provide for efficient administration. Coordination is the essence of the presidential process.

While it may usually not be visible to outside observers, the President can, and does, draw on a broad range of staff resources to help discharge his coordinative functions, including (I) his immediate White House staff; (2) the Council of Economic Advisers, which, for example, gave a strong initial impetus to the develop-

\footnotetext{
11 U.S. Prestdents, Public Papers of the Presidents of the United States, Lyndon B. Johnson, I963-1964, Bk. II, at I657 (1965).

${ }_{12} 78$ Stat. 53I, as amended, 42 U.S.C.A. $\$ 2945$ (Supp. 1965).

${ }^{13}$ White House Press Release, Jan. 28, 1965, and 79 Stat. 973, 978.
} 
ment of the antipoverty effort; ${ }^{14}$ (3) the Bureau of the Budget for advice and assistance relating to the organization and management of the executive branch, coordination of legislative proposals, program evaluation and programming of resources, and preparation and execution of the federal budget; (4) the Office of Economic Opportunity, whose Director is the President's chief assistant in the "war on poverty," and the Cabinet-level Economic Opportunity Council; and (5) the whole circle of Cabinet officers and agency heads who are responsible for carrying out the policies set by the President under laws enacted by the Congress, and whose assistance and cooperation is more often than not welded together through the units in the Executive Office-in which the Bureau of the Budget serves as a principal institutional coordinating mechanism.

\section{B. Policy Control by the Congress}

Congress determines national policy in these far-sweeping poverty programs through substantive legislation and the appropriation process. At least ten committees of the House and Senate share in the important function of developing the legislation which determines the nature, shape, and magnitude of the federal programs combating poverty; and additional committees participate in the oversight process. The House Committee on Education and Labor and the Senate Committee on Labor and Public Welfare have an especially important role because they are responsible both for the Economic Opportunity Act and for the bills on education. ${ }^{15}$ Education has been described by the President on several occasions as the major weapon against poverty. The latter committee also handles public health bills.

The House Committee on Ways and Means and the Senate Finance Committee also have a very large role, not only because they are responsible for revenue legislation but because they have in their control social security bills covering cash aid, welfare services, and increasingly important medical care programs. Old-age, survivors and disability insurance and public assistance are today, respectively, the largest providers of federal funds to the poor. The House Committee on Interstate and Foreign Commerce handles public health legislation; and the House Committee on Veterans Affairs is responsible for veterans' bills, which provide pensions and medical benefits to needy veterans. The House Agriculture Committee and the Senate Agriculture and Forestry Committee have the principal role on legislation affecting farmers and other rural residents. Finally, the Appropriations Committees

\footnotetext{
${ }^{14}$ See Prestdent, Economic Report, 1964 , at $55-84$ (1964), for a clear marshalling of the facts on poverty following the President's January 1964 State of the Union message, in which he declared all out war on poverty in America.

${ }^{15} \mathrm{Sec}$, e.g., Hearings on Examination of the War on Poverty Program Before the Subcommittee on the War on Poverty Program of the House Committee on Education and Labor, 89th Cong., Ist Sess. $\mathrm{I} \rightarrow \mathrm{f}$ (1965) (opening statement by Chairman Adam C. Powell, criticizing umbrella agencies for hindering creative programming and involvement of the poor).
} 
of the House and Senate exercise profound influence on the course and size of federal programs by their actions on appropriations recommended by the President.

Within all these committees there are numerous subcommittees, and additional legislation is handled by other committees.

\section{Coordination Through the Allocation of Federal Resources}

The setting of action goals and the allocation of federal funds to achieve them is perhaps the single most important and powerful focus for coordination of the antipoverty effort today. The effort to eradicate poverty requires multi-purpose, multi-program, long-term endeavors. Resources must be allocated with a careful balance between the short-run relief and long-term human investment programs, between income transfer programs for the aged and education, training, and health services for youth; between programs for redevelopment of physical facilities and human renewal and rehabilitation; between innovative but untried programs and established but often non-dynamic existing programs.

The budgetary process is the federal government's chief action-forcing mechanism for coordination. The budgetary review involves not only allocation of resources but scrutiny of administrative efficiency and questioning of organizational assignments.

President Johnson's budget recommendations for the fiscal year Ig67 include estimated expenditures of $\$ 2 \mathrm{I}$ billion for federal benefits and services to the poor from administrative budget and trust funds-an increase of nearly $\$ 4$ billion over I966 and $\$ 8.6$ billion over actual 1963 outlays. $^{16}$ This $\$ 2$ I billion is the estimated portion for the poor out of a total $\$ 45$ billion in "great society" and other related programs, and it represents nearly r4.5 per cent of all cash payments to the public from administrative budget and trust fund accounts. Additional benefit will be derived by the poor from the remaining expenditures in the budget, although no one has estimated what their total share may be.

Of the total of $\$ 2 x$ billion identified for the poor, expenditures from funds appropriated to the President for the new programs under the OEO comprise \$r.6 billion, or 7.5 per cent. The Department of Health, Education and Welfare accounts for 68 per cent, including $\$ 8.6$ billion from the social security and health insurance funds and an additional $\$ 5.9$ billion from appropriated funds. The remaining $\$ 5$ billion, or 24 per cent, is distributed among nine other agencies-the Departments of Labor, Agriculture, Housing and Urban Development, Interior, and Commerce, the Veterans Administration, the Small Business Administration, the Railroad Retirement Board, and the Appalachian Regional Commission.

The federal government's efforts to assist the poor are more clearly revealed by looking at the purposes for which the $\$ 2 x$ billion will be expended in fiscal 1967 :

\footnotetext{
${ }^{10}$ See The Budget of the United States Government, I967, at 126 (1966). For a useful brief description of many of the programs mentioned below see SAR A. Levitan, Programs in Aid or THE POOR (1965).
} 
(I) $\$ 7.3$ billion will be for old-age, survivors, and disability insurance payments by HEW, an increase from $\$ 5.3$ billion in $x 963$ and $\$ 6.9$ billion in 1966 .

(2) Other cash benefit payments will total $\$ 5.4$ billion in 1967 , compared with $\$ 4.8$ billion in 1963 and $\$ 5.4$ billion in 1966 . In 1967 public assistance grants to states by HEW, exclusive of medical care and services, will total $\$ 2.4$ billion. Veterans Administration compensation and pension payments directly to individuals will be $\$ 2.3$ billion. The remainder of $\$ .7$ billion is unemployment insurance benefits by the Labor Department and Railroad Retirement Board payments.

(3) Education and training programs will total $\$ 2.8$ billion in 1967 . They show the sharpest rate of increase, rising from $\$ .2$ billion in 1963 and $\$ \mathrm{r} .3$ billion in $x g 66$. The new Elementary and Secondary Education Act of $1965^{17}$ accounts for \$I billion and the Economic Opportunity Act of $\mathrm{Ig} 64$ for about $\$ .8$ billion of the total in 1967. The remainder includes the manpower development and training activities of the Department of Labor, education services to Indians by the Department of the Interior, and other HEW programs.

(4) Health benefits and services will also total $\$ 2.8$ billion in 1967 , compared to $\$ 1 . I$ billion in 1963 and $\$ 1.5$ billion in 1966 . The 1967 total includes $\$ 1.2$ billion for the new Medicare and supplemental health programs for the aged. About $\$ .8$ billion is for medical care under public assistance, and the remainder consists of a variety of $\mathrm{HEW}, \mathrm{OEO}$, and Veterans Administration health activities.

(5) All other aids, including a large variety of services and programs for economic and community redevelopment, will account for about $\$ 3$ billion of expenditures in I967, compared with $\$ \mathrm{x} .4$ billion in 1963 and $\$ 2.5$ billion in $x 966$. Included in this total is nearly $\$ .8$ billion for Agriculture Department programs, of which direct food distribution and food stamp programs are the largest. Public housing, urban renewal, and other aids by the new Department of Housing and Urban Development account for $\$ .4$ billion. Welfare, employment, small business, and community and economic development programs account for much of the remainder.

About $\$ 9$ billion of the total of $\$ 2$ billion is for programs specifically restricted to the needy-such as the OEO programs, public assistance, Veterans Administration pensions, educational aid for children of poor families. The remainder represents other programs which aid the poor as part of their broader role.

The concept of a total "war on poverty" is still, as governmental endeavors go, a very new one. No single, agreed-upon grand strategy pervades these programs. There is not in them a neat correspondence between the single stated need of overcoming poverty and a carefully balanced and coordinated action plan. Exceedingly significant new initiatives have come out of the effort to mold a "great society." Yet many of the existing programs date back to the "new frontier," "fair deal," "new deal," and even earlier days. They are the accumulated product of hundreds of laws winnowed out of thousands of bills introduced in the Congress. Their character is

\footnotetext{
${ }^{17} 79$ Stat. 27 (codified in scattered sections of 20 U.S.C.A. (Supp. I965)).
} 
often embedded solidly in laws, precedent, philosophies, and institutions which can be changed or redirected only with great effort. Coordination and interrelationship of programs were not heavily stressed when they were created. Agency and professional jealousies, often mirroring the views of supporting private groups and organizations, reinforce this compartmentalization. All but a few of the programs serve purposes broader than aid to the poor.

Thus, while the President has enunciated and the Congress has adopted a national policy "to eliminate the paradox of poverty in the midst of plenty,"18 it is still too true, as Gunnar Myrdal observed in early I964, that "in almost all respectsminimum wages, Social Security, agriculture, housing, etc.-American economic and social policies show a perverse tendency to favor groups that are above the level of the most needy."10

The strongest brand of "presidential government" can remold or give new direction to such established programs only with the greatest of difficulty and only gradually. In many instances, this can only be done if the Congress enacts legislation.

Decisions relating to commitments of federal financing resources to particular programs are made principally through the legislative and budgetary processes. The principal machinery which the President uses to achieve coordination on such decisions are the staff units through which the White House develops the administration's legislative program and the President's budget. This machinery has developed through the years to become highly responsive to the President's wishes. It is supported by a general-purpose staff in the Bureau of the Budget which serves as an institutional coordinating resource capable of reaching, on short notice, into the far corners of any agency to bring forth information and response. On the question of how much to spend for any program, and on the balance of funds for antipoverty programs against the legions of other demands on the federal budget, the decision is uniquely the President's.

The OEO role in advising the President on the allocation of resources is still emerging. OEO representatives may participate on administration task forces or work groups endeavoring to develop new program ideas. OEO develops an overall plan for combating poverty which provides a basis for considering the financial needs of OEO and some of the needs of other agencies. However, along with other agencies, the OEO presents its requests for funds to the President through the Budget Bureau. It also reports on legislation to the Budget Bureau or to the White House as do other agencies.

A measure of coordination can be achieved by filling the gaps in existing programs-either by adding new ones or by expanding old ones. The all-out "war on poverty" has been enthusiastically received by the federal establishment. Many agencies have sought and found a significant way to relate their activities to the

\footnotetext{
${ }^{18}$ Economic Opportunity Act of $1964, \S 2,78$ Stat. 508, 42 U.S.C. $\$ 2701$ ( 1964 ).

${ }^{10}$ Myrdal, The Matrix, in Poverty in PLenty 118,122 (Dunne ed. 1964).
} 
new objective. On the whole, opportunities to establish new programs or to authorize additional funds have evoked a particularly ready and willing response among the agencies. They are typically dominated by established laws and purposes, and it is much easier to add new programs than to reallocate funds. In I965, a number of major new programs were enacted, including the Elementary and Secondary Education Act of $1965^{20}$ and the Social Security Amendments of $1965,{ }^{21}$ which make particularly large contributions toward the "war on poverty." Many other major laws in the education, health, vocational rehabilitation, housing and urban development, economic development, and other fields were also enacted.

Despite the limitations of a stringent budget in a period of international uncertainty, major new legislative proposals of great importance to the "war on poverty" are included in the President's I966 legislative program. One of the most important is the $\$ 2.3$ billion, six-year city demonstration program which includes provision for both urban and human renewal. Other proposals include legislation to increase the income criterion for allocating aid under the Elementary and Secondary Education Act of 1965 from $\$ 2,000$ to $\$ 3,000$ per family in fiscal 1968 , to raise the minimum wage and to extend protection of the Fair Labor Standards $\mathrm{Act}^{22}$ to over five million more workers, to provide improvements in the unemployment compensation system, to strengthen programs giving assistance to unemployed parents of needy children, and to improve the nutrition of needy children.

The budgetary process also provides an important tool for redirecting programs so that they concentrate more on helping the disadvantaged. The rg67 budget, through proposed legislation or administrative action, reflects redirection of the manpower development and training program to concentrate more on training the less skilled; the school lunch and special milk program to focus more on needy children; the public assistance program to provide more financial aid and better medical care to families with dependent children; and the federal-state vocational rehabilitation program to enroll more handicapped persons for receiving public assistance. ${ }^{23}$

It is altogether clear, however, that the available tools for measuring the effectiveness of federal programs are not precise. Even in the OEO where a strong program analysis staff has been assembled, programs are new and judgments regarding their effectiveness are largely a priori. The President has directed all agencies in the executive branch to develop and introduce a new planning-programming-budgeting system which will "incorporate the most modern management techniques now used in government and industry." ${ }^{24}$ This new approach will certainly be directed to measuring the effectiveness of programs in combating poverty.

\footnotetext{
${ }^{20} 79$ Stat. 27 (codified in scattered sections of 20 U.S.C.A. (Supp. 1965)).

2179 Stat. 286 (codified in scattered sections of 26, 42, and 45 U.S.C.A. (Supp. 1965)).

${ }^{22} 52$ Stat. 1060 (1938), as amended, 29 U.S.C. $\$ \S 201-19$ (1964).

23 The Budget of The United States Government, 1967, at 27-28 (1966).

24 Id. at 33 .
} 


\section{III}

\section{The Role of the Office of Economic Opportunity}

The Economic Opportunity Act of 1964, with its sweeping commitment to a social goal with very broad implications, represents a new departure in public administration. It has far-reaching significance for coordination of public and private nationwide action to achieve the major national goal of eradicating poverty. Its new features include: (x) A sweeping "clientele" approach concentrating on the then thirty-five million poor, as distinct from the typical, although not exclusive, focus of agencies and programs along "functional" lines. The new programs extend even where present agencies follow clientele lines-as does the Veterans Administration or the Department of Agriculture. (2) Strong emphasis on programs to help children and youth, bespeaking a long-term human investment approach for breaking the intergenerational cycle of poverty. (3) A heavy emphasis on direct federal aid to local communities, in contrast with the typical pattern of federal aid through the states. (4) The invention of the community action program concept to spark the creation of new institutions and to serve as an innovating and coordinating mechanism in local communities. (5) Authorization of nine other additional or "gap filling" programs. (6) The creation of the OEO with broad authority, already described in an earlier section, ${ }^{25}$ to help the Director assist the President in the coordination of the overall federal antipoverty effort.

In many respects this was a frankly pragmatic and experimental approach to a pervasive, long-standing national problem.

\section{A. Over-All Leadership Functions of OEO}

In the leadership arena, the OEO still largely is defining its role. Although the OEO is in the Executive Office of the President, an echelon higher than the regular department, pressures have led it to lean more toward its functions as an operating agency, rather than toward those it possesses as a coordinating agency. Perhaps this is understandable in these early phases, because the "heat was on" to get the new programs "off the ground." This has, however, introduced a competitive element into a situation where $\mathrm{OEO}$ may endeavor to coordinate activities of other agencies, although it has also given OEO certain leverage to bring about a common alignment of agency programs.

On the broader front of planning and resource allocation, OEO has a strong staff for research plans, programs, and evaluation. In the summer of 1965 , a government-wide survey was made by the $\mathrm{OEO}$ of programs operated by other agencies which contribute to the "war on poverty." This survey was useful as background information in the preparation of the 1967 federal budget and in the development of the OEO's own budget. But a great deal of action is still required to utilize fully

\footnotetext{
${ }^{25}$ See text accompanying notes 10-13 stupra.
} 
the OEO's broad authority under the preference provisions of the Economic Opportunity Act with respect to programs of other agencies. This is discussed further in a subsequent section.

\section{B. The Operating Programs of OEO}

The ten programs authorized by the Economic Opportunity Act of Ig64 have involved the OEO in a wide variety of interagency and intergovernmental relations. Perhaps no other operating agency in the federal government has as numerous relationships with other federal agencies as OEO has developed in a year and a half.

About half of the new OEO programs were essentially extensions of existing federal programs, although their beneficiaries were confined to the "poor." With the concurrence of the President, six programs have been delegated by the OEO to federal agencies that administer related broader programs:

(r) The Neighborhood Youth Corps, covering both in-school and out-of-school projects, scheduled to aid some 350,000 youths in 1967 , is being administered by the Manpower Administration in the Department of Labor. Some Neighborhood Youth Corps projects, however, are sponsored by local Community Action Agencies or by their delegate agencies.

(2) The Work Experience project grant program, largely paralleling the community work and training program under public assistance, and estimated to provide aid to r05,000 trainees in 1967 , is administered by the Welfare Administration of $\mathrm{HEW}$. It has arrangements with the Adult Basic Education program for support.

(3) The Adult Basic Education program, with an expected enrollment of 75,000 individuals in 1967 , is being operated as a grant-in-aid program by the Office of Education in HEW.

(4) The two-part Rural Loan program is being administered by the Farmers Home Administration in the Department of Agriculture.

(5) The Small Business Loan program has been delegated to the Small Business Administration, although the creation of small business development centers is often ticd to local community action agencies.

(6) The College Work Study program, originally delegated to HEW, has been entirely transferred to that department by the Higher Education Act of $1965 .{ }^{26}$

The remaining four programs are being operated directly by OEO:

(x) The Job Corps program, consisting of conservation centers for men and urban training centers for men and women, is scheduled to have r24 centers with a capacity of 45,000 by the end of fiscal 1967 , and is being directly operated by OEO. Contractual agreements have been made with (a) the Department of Agriculture and the Department of the Interior for the operation of the conservation centers, (b) the Department of Labor for recruitment and placement of enrollees, and (c) the Department of Defense for handling their pay. Contracts with private

\footnotetext{
${ }^{20} 79$ Stat. 1219, 20 U.S.C.A. $\$ \$$ roor-r 444 (Supp. 1965).
} 
firms and nonprofit agencies have been made for operation of the urban training centers.

(2) VISTA is likewise being directly operated and is scheduled to utilize 4,500 volunteers by June 30, 1967 .

(3) The Community Action Program, which involves the making of grants to nonprofit and public agencies, is the largest and most far-reaching direct OEO operation.

(4) The Migrant Assistance program is operated as part of the Community Action Program.

\section{Emerging Mechanisms of Interagency Coordination by OEO}

Although delegation has scattered the new programs under the Economic Opportunity Act, the OEO coordinating role is strongest with respect to OEOfinanced programs. With respect to these programs, the OEO exercises various controls over basic policy decisions and retains full coordinating authority by such means as: exercise of the power of the purse through allocation of funds, from the single OEO appropriation, among the various programs delegated and directly operated; entering into memoranda of agreement with the other agencies to which the several programs have been delegated, and further reinforcing control through jointlyapproved regulations; holding frequent, usually weekly, meetings with top officials from agencies operating such delegated programs; requiring reports on operations, on proposed use of funds, and on recommended budget requirements; using the fungible Community Action Program resources in conjunction with the various delegated programs-for example, to enrich Neighborhood Youth Corps projects, to finance Youth Opportunity Center personnel in Community Action Program projects, or to participate in multiple agency financing of projects; and utilizing on a contractual basis specialized services of other agencies-such as those of the U.S. Employment Service for Job Corps recruitment and placement of Job Corps recruits-thereby achieving closer relationships with other ongoing programs.

As might be expected, especially numerous relationships are growing up between the $\mathrm{OEO}$ community action programs and other agencies of government. Interagency agreements, formal and informal, on a bilateral basis between OEO and other departments and agencies are à major OEO technique for achieving coordination of planning and action at the federal level. Responsibility for initiating these interagency agreements rests with OEO's Office of Interagency Relations, a top level staff office within the Office of the Director. These agreements provide the basis for joint action, for joint funding of projects, and for maintaining effective coordination of planning and operations at the federal and local levels.

A general "umbrella" agreement between OEO and HEW has widened coordination between the two agencies. Under this agreement HEW has made available its personnel to $\mathrm{OEO}$ on a reimbursable basis; and OEO has funded 
special poverty coordinators in seven HEW regional offices, as well as in the Office of the Secretary. A joint OEO-Office of Education unit for the education of the disadvantaged-established by agreement between OEO and the U.S. Commissioner of Education-has facilitated cooperation on special education programs, such as Head Start, remedial tutorial programs, and title one of the new Elementary and Secondary Education Act of $1965 .{ }^{27}$

Under the "umbrella" agreement with HEW, the Public Health Service has also lent its support in the development of new Community Action Program projects - such as neighborhood health centers, the Home Health Aides program, health and dental care services in Head Start, and the expansion of medical care to the needy under the new Social Security Amendments of $1965 .{ }^{28}$

Other joint agreements between the constituent agencies of HEW and OEO led to the development of the Foster Grandparents program (Administration on Aging); "operation medicare alert" and a training program for Bureau of Federal Credit Unions (Social Security Administration); training of home health aides (Public Health Service); a joint rehabilitation project in California (Vocational Rehabilitation Administration); and provision of services for female applicants with dependent children wishing to enroll in the Job Corps (Welfare Administration).

Agreements with the Department of Labor have provided for coordinated action in the development and location of youth opportunity centers in conjunction with local community action programs leading to the out-stationing of youth opportunity centers personnel in many neighborhood centers; screening of the vast majority of Job Corps enrollees by state employment service agencies; reimbursements for employment service personnel stationed in community action program neighborhood centers; and funding of positions within various bureaus of the Department of Labor and within OEO.

An important multi-agency agreement on coordination of manpower programs developed by the President's Committee on Manpower sets the stage for cooperative action by the Labor Department, OEO, and HEW in thirty cities through a threemember selected cities task forces. Labor and OEO also have several jointly-funded projects, including the Star project in Mississippi aimed at 25,000 severely undereducated people, youth training projects in Watts in Los Angeles, and skill centers in New Haven.

Close cooperation between OEO and the Department of Agriculture has enabled antipoverty programs to be launched in rural America with greater speed and comprehensiveness than would otherwise have been possible. A recent agreement with the Department of Agriculture will provide closer coordination between OEO's Rural Task Force and the Rural Community Development Service, the Federal Extension Service, the Rural Electrification Administration, and the Farmers' Home

\footnotetext{
${ }^{27} 79$ Stat. 36,20 U.S.C.A. $\$ \$ 821-27$ (Supp. 1965).

${ }^{38}$ Sec. 121 (a), 79 Stat. 343, 42 U.S.C.A. $\$ \S 1396-96 d$ (Supp. 1965).
} 
Administration. The Department of Agriculture has provided valuable services in initiating Head Start and Community Action Program projects in rural areas and in recruiting for Job Corps and Neighborhood Youth Corps enrollees.

Close ties are maintained between OEO and the public housing and urban renewal activities of the new Department of Housing and Urban Development. Cooperation by Department of Justice officials has speeded the launching and development of the new Legal Services program. The Appalachian Regional Commission and OEO exchange information on project proposals and on statistics pertaining to the Appalachian region. There is a continuing relationship between $\mathrm{OEO}$ and the Bureau of Indian Affairs in the Department of the Interior in developing antipoverty programs on Indian reservations.

\section{The Complex Skein of OEO Relationships}

Perhaps no other agency in the federal government has such far-flung relationships with public and private agencies and organizations as OEO. Except for the limitation in section 205 of the Economic Opportunity Act that the community action program funds may not be used for "general aid to elementary or secondary education,"29 OEO may finance virtually any antipoverty program, even if a similar program is being carried on by another agency. Any public agency or private nonprofit group, except a political party, may be used. Thus OEO is supporting local projects in an extremely wide variety of fields, cutting across the lines of many other federal agencies.

The historic drive to provide opportunity for the poor was planned to mobilize not only the energies of government but also of private organizations and individuals. Many thousands of people from all walks of life-businessmen, educators, labor officials, social workers, public administrators-have made themselves available for service in this effort. OEO has involved numerous advisory groups in its activities. The National Advisory Council, specifically authorized by the Economic Opportunity Act, has met four times in the past year to discuss policies, issues, and problems. Groups such as the Business Leadership Advisory Council, Labor Advisory Council, Community Representatives Advisory Council, and Public Officials Advisory Council have been established to provide OEO with expert advice and guidance. In addition, national advisory committees on Legal Services, Head Start, and the Older Poor make available a wealth of experience. Other groups, such as Women in Community Services, and the Inter-Faith Planning Committee on Poverty, also have provided much assistance and have added to the broader understanding of the "war on poverty," which in hundreds of communities is being translated into action through community action agencies involving a wide variety of interests on their governing boards.

\footnotetext{
${ }^{29}$ Sec. 205 (b), 78 Stat. 518, 42 U.S.C. $\$ 2785$ (b) (1964).
} 


\section{IV}

\section{Coordination of Antipoverty Efforts at Local, State, and Regional Levels}

One of the main purposes of the Economic Opportunity Act is comprehensive action and coordination of action against poverty. It emphasizes local initiative and voluntary action, buttressed by federal financial assistance covering ninety per cent, or even one hundred per cent, of project costs. A principal objective is to create opportunities for the impoverished to help themselves. Strong authority is provided for coordination, but there is also great flexibility. ${ }^{30}$

The major new thrust in the Economic Opportunity Act is the Community Action Program concept. The objectives of the community action programs are to call upon the huge reservoir of local initiative, to fill gaps in the spectrum of existing programs, and, above all, to provide mechanisms for coordinated local planning and action. In his first message on poverty, President Johnson stated:

... through a new community action program we intend to strike at poverty at its source-in the streets of our cities and in the farms of our countryside among the very young and the impoverished old. This program asks men and women throughout the country to prepare long-range plans for the attack on poverty in their own local communities. ...

These plans will be local plans striking at the many unfilled needs which underlie poverty in each community, not just one or two. Their components and emphasis will differ as needs differ. These plans will be local plans calling upon all the resources available to the community-Federal and State, local and private, human and material ....31

Although nine other programs were also authorized, the heart of this commitment was embodied in title two of the Economic Opportunity Act which authorizes "Urban and Rural Community Action Programs" to provide stimulation, incentives, and resources to combat poverty. ${ }^{32} \mathrm{~A}$ community action program is a program which is operated in "any urban or rural ... area ... including . . . a State, metropolitan area, county, city, town multicity unit, or multicounty unit"; provides "services, assistance, and other activities of sufficient scope and size to give promise of progress toward elimination of poverty or a cause or causes of poverty . . .; is developed and administered with the "maximum feasible participation of residents of the areas and members of the groups served"; and is "conducted, administered, or coordinated by a public or private nonprofit agency ... or a combination thereof." 33

\footnotetext{
${ }^{30}$ See March, Poverty: How Much Will the War Cost?, 34 Social Serv. Rev. I4I, 153-54 (1965).

${ }^{31}$ Message from the President of the United States Relative to Poverty, H.R. Doc. No. 243, 88th Cong., $2 d$ Sess. 4 (1965).

${ }_{32} 78$ Stat. 516,42 U.S.C. $\$ \$ 278 \mathrm{I}-9 \mathrm{I}(1964)$, as amended, 42 U.S.C.A. $\$ \S 2782,2785,2788,2789$ (Supp. 1965 ).

${ }^{30}$ Sec. 202,78 Stat. 516, 42 U.S.C. $\$ 2782$ (1964), as amended, 42 U.S.C.A. $\$ 2782$ (Supp. 1965).
} 
The first community action program grant was made in November 1964 . By the end of January 1966 more than 900 grants had been made to over $x, 000$ of the 3,300 counties in the United States, including more than 600 active community action agencies. All of the fifty largest cities, with a population of eight million poor people, had community action agencies. By the end of fiscal 1967 , it is estimated by OEO that community action agencies will be operating in more than goo urban and rural areas, which contain over three-fourths of the thirty-two million poor people in the nation within their jurisdictional boundaries. Moreover, in fiscal 1967 the community action agencies will probably provide some service to about one-fourth of the people in their boundaries, or to one-fifth of all the poor. In addition, planning projects will be funded during 1967 in an estimated 300 additional communities. Of the $\$$ r. 75 billion of appropriations recommended by the President for all OEO programs for fiscal 1967 , $\$ 914$ million is for community action programs, including $\$ 310$ million for Head Start projects.

\section{A. The Milieu for Community Action Programs}

Poverty has many manifestations and many roots, although some roots go deeper than others. Among the thirty-four million poor in 1964 , there were nearly fifteen million children and 5.4 million persons over age sixty-five. An estimated $\$ 12$ billion of additional income was needed to fill the poverty income gap of all these poor. ${ }^{34}$

The planning and conduct of a comprehensive attack on poverty requires the mobilization in a community of an extremely broad spectrum of community agencies and resources. The human resource thrust of the "war on poverty" clearly requires participation of employment, job training, health, rehabilitation, welfare, education, and related agencies. Since environment is important, the housing, urban renewal, and other agencies charged with providing community facilities must be included. Financial and manpower resources of both local, public, and voluntary agencies must be harnessed, and must be supplemented by resources that are provided by states and, beyond them, by the federal government. Coordination, both horizontally and vertically, is imperative at the local level. However, coordination is difficult because:

(I) Available federal resources are typically provided through categorical programs. OEO in 1965 listed about $25^{\circ}$ "programs" administered by fifteen agencies as related to the antipoverty mission. ${ }^{35}$ Almost every program has its own organizational, special eligibility, and financial provisions.

(2) The compartmentalization of federal programs is more often than not projected into the organization of states and through them into the localities. Education,

\footnotetext{
31 President, Economic Report, 1966, at II4 (1966).

${ }^{36}$ Catalog of Federal Programs for Individual and Community Improvement.
} 
health, welfare, and employment agencies all have their professional and their jurisdictional boundaries, across which they work only with reluctance.

(3) Federal, as well as state, funds are often distributed by allotment formulas, based on population, incidence of disease, area, or other special factors, in order to assure "equitable" distribution. The federal budget includes about 140 grant-in-aid programs, many of which contain allotment formulas. More often than not, federal grant-in-aid funds in the vital education and health fields are allocated to the states, which in turn distribute them to the localities. Even Community Action Program funds are apportioned among the states according to a statutory formula and among counties by a flexible administrative formula. It is extremely difficult for a locality to concert available resources and muster an enlarged, coordinated effort.

(4) Local communities, especially rural or small town areas, are confronted by vast information gaps and skill shortages. They may not have the know-how or professional personnel to keep informed of the rapidly emerging possibilities for financial or technical aid under state programs and, least of all, federal programs. Furthermore, to qualify for available grants, a locality has to muster a good deal of statistical information and fill out complicated forms.

(5) Resources for local public services are not only compartmentalized, but tend to be vested in public agencies which may or may not be responsive to the poor people in the community or to coordination by a new "umbrella" agency. The OEO utilizes both public and private resources in community action programs and requires "maximum feasible participation" of residents of the areas and members of the groups served in community action agencies. Approximately seven out of ten of the community action agencies are private or mixed public-private nonprofit corporations, further complicating community relationships. Such agencies have the advantage of flexibility enjoyed by private corporations. But as "private" agencies they may often have limited capacity to raise the required local share of project costs or otherwise to engage the energies of the local public organizations. ${ }^{36}$ However, since most of the mixed corporations are joint public-private ventures, it may work out that public resources at the local and state levels will be channeled into them readily, just as federal funds are now provided to them.

Not only is the problem of organizing in local communities complex, but to be effective the new resources of the portion of the "war on poverty" financed by the OEO must be used so as to achieve a leverage or multiplier effect-by which resources of local communities, states, and other federal agencies will be involved to the utmost.

\section{B. Allocation of State, Local, and Private Nonprofit Resources for the Poor}

The 1962 Census of Governments reported more than 9r,000 units of state and local government in the United States. There is no similar comprehensive enumeration of private voluntary agencies, but it has been estimated that there are 200,000

\footnotetext{
${ }^{30}$ Sec, e.g., Loftus, Oakland Is Split On Poverty Plans, N.Y. Times, Jan. 17, 1966, p. 20, col. 1.
} 
such organizations, plus 300,000 churches, in the United States. ${ }^{37}$ State and local governments and private voluntary agencies already play a major role in helping the poor. Expenditures aiding the poor by state and local governments-according to a study for the OEO covering the years $1963-1964^{38}$-approached $\$ 13$ billion and included: nearly $\$ 4$ billion for current expenses of elementary, secondary, and vocational education or training; more than $\$ 3$ billion for community facilities, such as school, medical, transportation, utility, and similar facilities; more than $\$ 2$ billion for direct financial assistance through general relief, unemployment insurance, temporary disability insurance, and workmen's compensation programs; more than $\$ 2$ billion for physical and mental health services; and more than $\$ \mathrm{r}$ billion for social rehabilitation-that is, costs of operating correctional institutions and combating juvenile delinquency.

While the foregoing figures include many rough estimates, they are conservative in one major respect: They exclude state and local expenditures where the federal government provides more than fifty per cent of the program cost. Thus, they omit about $\$ 2$ billion of state and local outlays for old-age assistance, aid to the blind, aid to the permanently and totally disabled, and aid to families of dependent children.

According to the same study, private voluntary agencies spent nearly $\$ 2.5$ billion to assist the poor, including more than $\$ \mathrm{I}$ billion for educational services and nearly a half billion dollars for health services. Thus, expenditures by state, local, and private voluntary agencies for the poor were in the neighborhood of $\$ 17$ billion in I963-1964 and will certainly have increased considerably by fiscal 1967 .

The allocation of these financial resources is accomplished through an almost infinite diversity of governmental organs and private boards under widely-varying policies. The bulk of these expenditures which assist the poor are only parts of broader programs. Only a few, such as public assistance, are directed entirely to the needy. In some programs, such as education, the poor may-often do-receive less than their pro rata share. Recognition that many social and economic problems were going unmet in this highly decentralized system of pluralistic government has been one of the principal factors leading to the creation, during the past several decades, of numerous categorical federal grant-in-aid programs which seek to direct assistance according to need and financial ability, and to encourage states and localities (and, in some cases, private nonprofit agencies) to engage in activities which may otherwise not be carried on. ${ }^{39}$

In the face of large unmet needs, the dominant concern until the "war on

\footnotetext{
${ }^{37}$ Robert H. Hanlin, Voluntary Health and Welfare Agencies in the United States 9 (I96r).

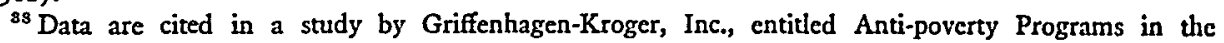
United States, prepared for the Office of Economic Opportunity in July r965. The data on funds in this section are from this study.

${ }^{30}$ See Special Analyses, Budget of the United States, Fiscal Year 1967, particularly Spccial Analysis J on "Federal Aid to State and Local Governments," which estimates a total of more than \$1 4.6 billion of such aid from budget and trust accounts for fiscal year 1967 .
} 
poverty" began had been to create and develop new programs, rather than to worry about their coordination. Thus, as pointed out earlier, local and state resources may be constricted into narrow compartments where they match existing federal programs. Most of the OEO programs also follow in this categorical pattern; but the community action programs are very broad because the spectrum of causes for poverty is broad. In view of the broad powers of OEO under this program, the challenge is clear: Will OEO be able to exercise the leverage of its flexible funds and preference provisions to contribute materially to the concerting of resources and action in the many other on-going programs? ${ }^{40}$

\section{The OEO Building Block Approach}

Although armed with substantial authority to require priorities and coordination based on comprehensive local plans, the OEO thus far has leaned heavily on a "building block" approach. The Economic Opportunity Act does not require comprehensive planning; and OEO has recognized that many communities, at the outset, were unable to initiate coordinated community action programs which would link different programs and service systems. Accordingly, communities were permitted to move forward to secure approval for "component projects" while they were engaged in program development and before they had a comprehensive community action program. ${ }^{41}$ As of late January 1966 , approximately 600 community action agencies had received funding for nearly 2,900 action components-that is, an average of about five per community action agency. ${ }^{\mathbf{4 2}}$

This step-by-step approach under the Economic Opportunity Act has contrasted sharply with the emphasis on pre-planning that had been required for grants under the Juvenile Delinquency and Youth Offenses Control Act of $196 \mathrm{r}^{43}$ The comprehensive planning under that act, with its strong emphasis on evaluation, was in many ways the prototype for the community action programs, but it had been criticized as too slow. OEO is considering trial of a broader approach in the community action field in a few cities in the months to come.

Components of community action programs are typically developed by separate committees or community organizations, with little implementation of overall

\footnotetext{
4" For various impressions regarding the effectiveness of coordination in the poverty program see II Office of Economic Opportunity, Congressional Presentation 93-Ii 6 (i966); U.S. Conference of Mayors, Special Report: The Office of Economic Opportunity and Local. Community Action Agencies (1965); U.S. Conference of Mayors, Economic Opportunity in Crries (i966); Spivak, AntiPoverty Flaw, Wall Street Journal, March I, I966, p. I6, col. 4; series on poverty programs entitled The Better War in Washington Post, Jan. 30-Feb. 13, 1966, particularly the story "Maximum Feasible Participation" of Poor Has Not Yet Been Realized, Feb. 4, p. I, col. 2.

12 Office of Economic Opportunitx, Communtry Action Program Guide, Instructions for AppliCnNTS 22 (1965).

12 New Haven, Connecticut, often is cited as the outstanding example of a community action program. Other cities often cited as showing good progress include Detroit, Pittsburgh, Atlanta, and Oakland, Cal. See address by Sargent Shriver to the AFL-CIO Convention, Dec. 9, I965 (quoting United Press International survey).

${ }^{13} 75$ Stat. 572 , as amended, 42 U.S.C. $\$ \$ 241-48$ (1964).
} 
priorities. Under the concept of local initiative, there are practical constraints on how much guidance as to priorities $\mathrm{OEO}$ can provide. Instead, it has focused more on questions of representation and getting the program going.

Even so, many communities have found the requirement of preparing successive project proposals and the attendant delays to be discouraging and wasteful of time and money. In other cases, $\mathrm{OEO}$ has been criticized for funding activities which duplicated going projects in the community.

An adjunct of the "component project" approach has been a tendency of the community action programs to develop a conglomeration of national programs, such as Head Start, Upward Bound, Foster Grandparents, Migrants, and Legal Services. Some of these may assume the status of independent programs. OEO has encouraged adoption of its "packaged" programs such as Head Start, Legal Services, and the like.

Within the community action program area, perhaps the most unified projects have been the neighborhood centers. By the end of December 1965, sixty-nine of the approximately 600 active community action agencies had received funding for a total of 175 neighborhood centers. In many respects, the neighborhood centers represent a move toward the concept of a "one-stop" social service center. The first objective was to move the focus of community service out into the neighborhood in which the poverty-stricken people reside. The second objective was to enable those who were seeking service to make contact at one location with as many of the services that they needed as possible. The most common functions of a neighborhood center are those of outreach, advice, intake, and referral. Individuals or families seeking help are interviewed and guided to other specialized agencies which might help them, such as health clinics or welfare offices. In many instances, community welfare, employment, and health agencies have placed some of their employees in the center to render service on the spot. For example, an estimated 166 centers had Youth Opportunity Center personnel or other personnel financed by the employment service available to help needy youth.

Other federally-financed agencies have also shown a strong tendency to move their services toward outlying neighborhoods. The guidelines for youth opportunity centers provide that they will be located by the employment service in fringe areas where they can be reached by all youth, and satellite youth opportunity centers have been set up in outlying poverty areas. Similarly, the Welfare Administration has reported that of the 3,500 public welfare offices in the United States, more than $35^{\circ}$ were decentralized to local neighborhoods.

The concept of concerting resources of local communities through physical relocation of the many public service agencies-welfare, health, rehabilitation, housing, vocational education, and employment-in one convenient location, with some common intake and referral unit, has not yet gotten very far. Families or individuals who need help often need assistance not only in establishing contact with 
community agencies but in working out the combinations and the sequence in which services can best aid them.

Nor has the present pattern of interagency community action, even as reinforced by OEO's broadened authority and resources, gone far enough in coordinating aid to local communities so that it would promote integration and relocation of existing and new programs in convenient one-stop locations. The concept of a "social service shopping center," housing most or all the local agencies sponsored by OEO, HEW, Labor, Housing and Urban Development, and other related agencies which finance programs that serve people, is undeveloped.

There is room for experimentation with broadening of the neighborhood center concept and with various patterns for concerting and providing a continuum of services at "one-stop" locations in communities, in neighborhoods, or even in whole urban areas. Action in this direction not only by OEO but also by other related agencies might provide speedier, more effective service to the citizens and eliminate duplicate paper work and overhead expenses.

\section{Coordination Through OEO's Check Point Procedure}

The OEO effort toward greater local coordination of the antipoverty projects is accomplished in two main ways: (I) by encouraging or requiring communities to develop comprehensive plans through their community action agency; and (2) by setting up requirements that there be an interaction between the community action agencies and other public community agencies, officials, and organizations in the development of community action program plans and encouraging such agencies to consult with the community action agencies on their proposed applications for assistance under other OEO, or other federal, programs. The authority of the OEO in this latter area lies largely in the preference provisions mentioned earlier. Since preference defined strictly in terms of priority access to funds may tend to lose its meaning when community action programs cover most of the poor population, the chief value of this authority may be in enabling $\mathrm{OEO}$ to promote more effective coordination at the local level.

The main OEO mechanism for interagency consultation at the local level is the socalled "check point procedure." An applicant for a Community Action Program project grant is responsible for ascertaining the relationship of the proposed community action program project to approved and prospective projects financed under other parts of the Economic Opportunity Act (Work Experience, Work Study, Neighborhood Youth Corps, Adult Basic Education), and to other related programs, whether federally, state, or locally financed. Thus, the OEO requires that before submission of an application, the community action agency must have checked its proposals with the chief elected official of the community, and, where the subject matter is appropriate, the local director of the state employment service, the super-

\footnotetext{
"See OFFICE of Economic Opportunity, op. cit. supra note $4 \mathrm{I}$, at 40-4I.
} 
intendent of schools, the director of the county welfare department, and other officials, such as the director of the local urban renewal, public housing, or public health agency, the local representatives of the agricultural extension service, the Farmers' Home Administration, and so on. Many community action agencies include these officials on their boards; and this is one of the most used techniques of local coordination in the poverty effort.

Conversely, arrangements have been made in the case of a few non-OEO financed programs for a "reverse check point procedure" in which agencies planning project proposals for federal aid under laws other than the Economic Opportunity Act must check with the local community action agency. At the present time, such a procedure is required only in two instances:

(I) Applications for federal assistance for education of children from lowincome families under title one of the Elementary and Secondary Education Act of $1965^{45}$ must, by law, be checked out by the local education agency with the community action agency, if there is one. Instructions by the Office of Education require that the application must be accompanied by a form indicating the position of the community action agency on the application. ${ }^{46}$

(2) Applications to the Department of Housing and Urban Development for neighborhood facilities grants, under section 703 of the Housing and Urban Development Act of $1965,{ }^{47}$ must be accompanied by a statement showing the relationship between such facility and the community action program and making reference to the specific community action program elements involved. The act authorizing this program specifies that priorities are to be given to projects which primarily benefit members of low-income families or further the objectives of the community action program. ${ }^{48}$

Section $\operatorname{ror}(a)(x)(A)$ of the Public Works and Economic Development Act of $1965^{49}$ authorizes the Secretary of Commerce to make grants for public works and economic development under that act if they will further the objectives of the Economic Opportunity Act. A procedure is being developed to provide community action program certification on such projects.

As of early 1966, the OEO had not promulgated specific forms and provided specific working staff for assuring that the required checks are made in the local communities and that the resulting information is delivered to officials in federal

\footnotetext{
${ }^{15} 79$ Stat. 27 (codified in scattered sections of 20 U.S.C.A. (Supp. 1965)).

"Office of Education, Dep't of Health, Education \& Welfare, Revised Instructions (ig66), accompanying Office of Education, Dep't of Health, Education \& Welfare, Guidelines: Special Programs for Educationalix Deprived Children (1965). See id. at 27-28 for requircments as to cooperation with community action agencies under Elementary and Sccondary Education Act of $1965, \$ 2$, 79 Stat. 30, 20 U.S.C.A. $\$ 24 \mathrm{Ie}(2)(7)$ (Supp. 1965).

17 79 Stat. 49I, 42 U.S.C.A. $\$ 3103$ (Supp. I965).

is Ibid. See Departarent of Housing \& Urban Developarent, Neighborhood Facitaty Guant Program (Letter No. NF-1, 1966).

1979 Stat. 552, 42 U.S.C. $\$ 3131$ (a)(I)(A) (Supp. r965).
} 
regional offices or in Washington who pass upon the applications for OEO grants. Such specific working procedures were in the process of development. Likewise, broadening of the check point procedure to the delegated OEO-financed programs and to other federal programs was under active discussion.

\section{E. Coordination at the State and Regional Level}

Under the Economic Opportunity Act, local communities deal directly with the federal government, except in the delegated Work Experience and Adult Basic Education programs, which HEW channels through the states. This de-emphasis of the role of the states departs from the prevailing pattern in the grant-in-aid programs, in which federal aid is mainly channeled through the states. ${ }^{50}$ The cooperation and the assistance of the fifty states is essential, however, in a country that has some 90,000 lesser governmental units. States control the distribution of billions in other federal grants and provide billions of their own to assist local communities. Thus far the state financial participation in the OEO antipoverty projects has been small.

States also have much of the technical expertise needed by local agencies, especially in rural areas. Section 209 of the Economic Opportunity Act established a basis for participation of the states in the community action programs. ${ }^{51}$ Grants to and contracts with state agencies are authorized to enable them to provide technical assistance to communities in developing, conducting, and administering the community action programs. Through December $1965, \$ 8.7$ million dollars in technical assistance grants had been made by OEO. By late January I966, all fifty states had established or designated offices to cooperate with OEO. A number of states had shown excellent progress by the end of fiscal 1965 , according to Sargent Shriver, Director of the OEO $:^{52}$ In Georgia multi-county units blanketing the state had been formed, and almost every county had been covered by an OEO grant; in Kentucky a state-wide child care and preschool program had been set up; in Missouri the state health department had received money to establish mobile dental clinics; and in New Jersey and California, action by state coordinators had stimulated rural communities to come in for program development at rates far faster than in rural areas in other states.

According to the $\mathrm{OEO}$, state technical assistance offices have contributed to many state governments a degree of coordination seldom achieved for other broad programs. Many such offices utilize interagency committees or have close relations with

\footnotetext{
${ }^{50}$ For an incisive and interesting review of the background and significance of the OEO poverty programs, especially of community action programs, for the federal system, see Davidson, Politics, Poverty, and the Netv Federalism, in W. E. UpJohn Institute for EMployment Research, Dimensions of Manpower Policy, Research, and Utilization (forthcoming). Another broad-scale cvaluation by the Advisory Commission on Intergovernmental Relations, of intergovcrnmental relations in the poverty effort, based on substantial survey data, should prove extremely useful when it is published.

6178 Stat. 519, 42 U.S.C. $\$ 2789$ (I964), as amended, 42 U.S.C.A. $\$ 2789$ (Supp. I965).

52 Address by Sargent Shriver, 57th Annual Governors' Conference, Minneapolis, Minn., July 20, 1965 .
} 
the planning agencies of the states. In California the state technical assistance office acts as central coordinator for state participation in OEO programs, utilizing quarterly meetings of an interdepartmental council and participation by the director of the state technical assistance office in the governor's cabinet deliberations on antipoverty subjects. In Colorado the state technical assistance office coordinates the state antipoverty activities through the Coordinating Council for Economic Opportunity. In New York antipoverty state efforts are coordinated by the state technical assistance office through the cabinet-rank governor's coordinating committee, which is chaired by the Executive Assistant to the Governor and of which the director of the state technical assistance office is executive secretary. ${ }^{53}$

The Economic Opportunity Act provides that the governor of the state may have the opportunity to review community action program applications for his state, although the original so-called "veto" provision was modified in the 1965 amendments to give the Director of OEO authority to override the governor's disapproval on community action program projects. ${ }^{54}$ Section rog of the act still permits proposed Job Corps Conservation Camps and Training Centers to be vetoed by the governor ${ }^{65}$ and section $60_{3}(\mathrm{~b})$ requires the consent of the governor for VISTA volunteers..$^{60}$

The problem of technical assistance and organization for community planning and action is difficult, both in metropolitan areas and rural areas. There is no set pattern for demarcation of planning areas, although clearly the 3,300 counties of the nation often have arbitrarily drawn boundaries and do not provide natural economic or social units for planning and action. At present, the federal government offers technical assistance directly to local communities, sometimes through the state. Community action programs may be flexibly organized. Early OEO tabulations, however, indicated that about three-fifths of the community action programs were on a county basis, one-fifth on a city basis, and one-fifth in multicounty or other units.

The planning process is an important tool of coordination. Various federal programs at the present time support or encourage "comprehensive" planning units for economic or social action:

(I) OEO is financing the formation of community action agencies which numbered more than 600 in January I966, and are projected to exceed 900 by the end of fiscal year 1967 , plus additional ones in the planning stage. The community action agencies operate in the human resources and opportunities area and are not usually oriented toward broader economic or community facilities planning.

(2) The Economic Development Administration of the Department of Commerce

\footnotetext{
53 II Office of Economic Opportunity, Congressional Presentation 93, 102-13 (1966).

54 Economic Opportunity Amendments of 1965, $\$ 16,79$ Stat. 975, 42 U.S.C.A. $\$ 2789$ (c) (Supp. $1965)$.

${ }^{55} 78$ Stat. 51 I, 42 U.S.C. $\$ 27 \times 9$ (1964).

${ }_{78} 78$ Stat. 530,42 U.S.C. $\$ 2943$ (b) $(1964)$.
} 
has sponsored the development of more than 800 overall economic development program organizations concentrating on economic base planning.

(3) The Housing and Home Finance Agency of the Department of Housing and Urban Development is providing funds to local public bodies for comprehensive planning of public housing facilities and to some 700 public agencies for urban renewal planning, including grants to some 150 communities for the development of comprehensive community renewal programs.

(4) The Department of Agriculture has encouraged the formation of more than 2,100 rural areas development committees to prepare comprehensive rural community development plans.

(5) The Appalachia program provides for additional economic planning units in that area.

Various other agencies have community planning approaches in effect or on the drawing boards. The Department of Labor is moving ahead with plans for broadly based community programs of human resources development to reach out to individuals in groups with the highest unemployment rates. Related task forces, under the President's Manpower Committee, have been established pursuant to an interagency agreement into which the $\mathrm{OEO}$ and other agencies have entered. Members of the task forces have been assigned specific responsibility as "city coordinators" of manpower programs in thirty major metropolitan areas. The objective is to determine how the total departmental resources can be most effectively deployed to solve manpower problems and to speed up action. The first experimental project involving cooperation of the Department of Labor and HEW, and the Office of Economic Opportunity, was undertaken in three slum areas of Chicago in December $1965 .{ }^{57}$ The Federal-State Employment Service System, which has nearly 2,000 offices, would play a major role in this new effort to renew manpower resources.

President Johnson has also proposed a major program for comprehensive redevelopment of slum neighborhoods through a $\$ 2.3$ billion six-year "Demonstration Cities Program." It would be administered by the new Department of Housing and Urban Development and would encompass planning and action for both physical and human renewal in an effort to transform slum neighborhoods into livable communities in sixty or seventy cities. ${ }^{58}$ Related legislative action has also been proposed to broaden the project grants under section 701 of the Housing Act of $1954{ }^{59}$ to provide support for community development districts designated by the Secretary of Agriculture in rural areas, towns, and smaller centers of population. The purpose is to help support surveys of resources and needs within these districts; to provide for coordinated and comprehensive planning for all public services,

\footnotetext{
${ }^{57}$ See Manpower Report of the President, and U.S. Dep't of Labor, a Report on Manpower Requireanents, Resources, Utilization, and Training 4-5, 82-83 (I966).

${ }^{88}$ City Demonstration Programs, H.R. Doc. No. 368, 89th Cong., 2d Sess. (I966).

${ }^{50} 68$ Stat. 640 , as amended, 40 U.S.C. $\$ 46 \mathrm{I}\left(196_{4}\right)$.
} 
development programs, and governmental functions; and to enable a continuing liaison of the local areas with federal and state agencies. ${ }^{60}$

The structure of regions and distributions of regional and field offices of the various federal agencies does not provide a fully effective pattern for coordination among federal agencies in the field or for convenient, coordinated relationships with individual states. The Office of Economic Opportunity has seven regional offices, to which the processing and approval of most Community Action Program applications has been decentralized. The Department of Health, Education and Welfare has nine regional offices, some located in different cities from those with OEO offices. The Department of Labor does not have overall regional offices; its bureaus have separate regional offices. The Neighborhood Youth Corps has seven offices; the Bureau of Employment Security has eleven; the Bureau of Apprenticeship and Training has thirteen. Regional boundaries among the three agencies in some regions are not coterminous. And even where the offices are located in the same city, they are frequently not in the same building. Just as local public agencies may not stress geographical convenience of the services for citizens, so the federal agencies do not always provide coordinated and geographically juxtaposed regional offices to assist the states and local communities in their dealings with the federal government. Even on OEO-financed programs there is no common basis for decentralization. Community Action Program projects under $\$ 500,000$ (\$250,000 for Head Start) may now be approved in the field. Applications under the delegated Work Experience program and Neighborhood Youth Corps program are still processed in Washington.

\section{ConcLusion}

Public and private voluntary agencies in fiscal 1967 will probably spend more than $\$ 40$ billion, more than five per cent of the gross national product, to assist the poor-about equally divided between federal funds and state-local-private public and nonprofit funds. Allocation and authorization of these resources is largely through broader programs which have aid to the poor as only one of their objectives. Perhaps only one-third of all these funds will be from programs restricted to the needy. Funds are authorized and administered by a host of pluralistic institutions. Federal funds are perhaps the most subject to central, coordinated review-although OEO has not, thus far, extensively used its powerful preference provisions. At the non-federal level, plurality of purpose in organizations is dominant.

The establishment of an Office of Economic Opportunity marks a major effort to create coordinate mechanisms at the federal and at the local community levels for focusing resources and providing improved, concerted administration to eradicate poverty. The states have not been as heavily involved.

Invention of the Community Action Program concept for involvement of public and private agencies in comprehensive planning and action and for taking the

\footnotetext{
${ }^{60}$ Rural Poverty Program, H.R. Doc. No. 367, 89th Cong., 2d Sess. (1966).
} 
initiative in combating poverty at the local level is a major, promising breakthrough. Such agencies have shown a capacity for innovation; the promise of comprehensive, coordinated action is yet largely unfulfilled. OEO is not alone, for many other efforts-most still in the beginning stages-are being made to develop comprehensive planning machinery.

At the national level, the OEO has only begun to have an impact in coordinating action. It has important assets of location in the Executive Office, strong legal sanctions for coordination, and substantial appropriations for grants covering ninety per cent or even one hundred per cent of costs for an almost unlimited spectrum of program purposes. But in a pluralistic, democratic society there are substantial obstacles to coordination. The magnitude of OEO's star in the galaxy of federal agencies is yet unmeasured.

The enactment of the Economic Opportunity Act of 1964, establishing a major national purpose of victory over poverty, provides an important prerequisite for effective coordination of efforts at the national, state, and local levels. It serves to heighten public understanding, to smooth the achievement of consensus, and to promote informal coordination. It serves to ease the coordination of planning and action against the incredibly complex, deep-rooted, multi-faceted problem which is poverty.

Overcoming the existing fragmentation of programs and compartmentalization of agencies, particularly at the local community level, serving multiple-problem clientele, in order to provide coordinated, convenient services, continues to be one of the great challenges facing American government. 